\title{
INTRACELLULAR LEVELS OF SODIUM AND POTASSIUM IN BULL SPERMATOZOA IN RELATION TO CELL METABOLISM
}

\author{
J. M. O'DONNELL \\ A.R.C. Institute of Animal Physiology, Babraham, Cambridge
}

(Received 21st December 1969)

Spermatozoa in a variety of mammals have been found to contain significantly more potassium and less sodium than the seminal plasma (Quinn, White \& Wirrick, 1965). Similar differences in concentrations of these ions between spermatozoa of marine invertebrates and the sea-water environment have also been reported (Steinbach \& Dunham, 1961). Quinn et al. (1965) employed the packed wet cell weight of spermatozoa for calculation of sodium and potassium content of the cells, and on this basis found evidence for active extrusion of sodium and accumulation of potassium by spermatozoa of dog (Quinn \& White, 1967), bull and ram (Quinn \& White, 1968). Steinbach \& Dunham (1961) measured both wet and dry weight of pelleted spermatozoa and thus were able to derive the concentration of alkali cations in the intracellular fluid, assuming the latter to be represented by the difference between wet and dry weight. While this approach has many shortcomings when applied to so unhomogeneous a cell as the mammalian spermatozoon, it does permit estimates of concentration gradients between cell and environment.

The present report describes a preliminary investigation of the distribution of sodium and potassium between cell water of bull spermatozoa and an artificial medium in which they were suspended under various metabolic conditions.

Fresh samples of bull semen were centrifuged at $1000 \mathrm{~g}$ at room temperature for $10 \mathrm{~min}$; the seminal plasma and debris were discarded; and spermatozoa washed twice by repeated centrifugation in an artificial seminal plasma ( $\mathrm{Na}$ citrate, $38 \mathrm{~m}$-mole; $\mathrm{NaCl}, 10 \mathrm{~m}$-mole; $\mathrm{KCl}, 50 \mathrm{~m}$-mole; $\mathrm{NaH}_{2} \mathrm{PO}_{4}, 1 \mathrm{~m}$-mole; $\mathrm{CaCl}_{2}, 6 \mathrm{~m}$-mole; $\mathrm{MgCl}_{2}, 5 \mathrm{~m}$-mole; fructose, $30 \mathrm{~m}$-mole; $\left.\mathrm{pH}, 7 \cdot 2\right)$. All subsequent manipulations of the cells employed this medium. For determination of extracellular space in pelleted cells, a trace of ${ }^{14} \mathrm{C}$-labelled sucrose was added to the cell suspension which was then centrifuged at $3000 \mathrm{~g}$ for $15 \mathrm{~min}$ at room temperature. (The validity of this procedure for the determination of extracellular space was established by repeated washing of the cells with unlabelled medium when the radio-activity of the successive supernatants delivered exponentially, as expected of a single compartment. ${ }^{14} \mathrm{C}$-labelled inulin and ${ }^{60}$ Co-EDTA gave the same results). A 5-ml suspension yielded $0.2 \mathrm{~g}$ wet pellet in centrifuge tubes fitted with a lower capillary section which was just large enough to contain the pellet and permit easy removal of the 
supernatant. The cell pellet was resuspended in unlabelled medium and the extracellular fluid estimated by comparing the activities of the original supernatant with that of the diluted extracellular fluid. Wet pellet weight was obtained and the pellets dried in air at $105^{\circ} \mathrm{G}$ to constant dry weight. Dried cell pellets were weighed, incinerated in concentrated $\mathrm{HNO}_{3}$ and diluted with distilled water. Sodium and potassium were measured by flame photometry. By correcting the wet pellet weight for extracellular fluid, the water content and sodium and potassium concentration in cell water could be calculated.

Analyses were made on fresh spermatozoa and on cells which were cooled slowly to $5^{\circ} \mathrm{C}$ by immersing a tube of sperm suspension in a relatively large volume of water at room temperature and cooling the whole for $24 \mathrm{hr}$. Cooled spermatozoa were re-incubated at $25^{\circ} \mathrm{C}$ for $2 \mathrm{hr}$. Before and after both cooling and re-incubation, the numbers of live spermatozoa in the suspension were estimated by the eosin-permeability method (Campbell, Hancock \& Rothschild, 1953).

TABLE 1

PELLET EXTRAGELLULAR SPACE, GELL WATER AND SODIUM AND POTASSIUM CONCENTRATIONS IN FRESH, COOLED AND RE-INCUBATED BULL SPERMATOZOA

\begin{tabular}{|c|c|c|c|}
\hline & $\begin{array}{c}\text { Fresh spermatozoat } \\
(15)\end{array}$ & $\begin{array}{c}\text { Cold-stored } \\
\text { (15) }\end{array}$ & $\begin{array}{c}\text { Re-incubated } \\
\text { (15) }\end{array}$ \\
\hline $\begin{array}{l}\text { Extracellular space }(\% \text { of pellet) } \\
\text { Cell water }(\% \text { wet weight) } \\
\text { Cell } \mathrm{Na} \text { (m-equiv./kg cell water) } \\
\text { Cell } \mathrm{K} \text { (m-equiv. } \mathrm{kg} \text { cell water) }\end{array}$ & $\begin{array}{l}45 \cdot 6 \pm 1 \cdot 3 \\
53 \cdot 4 \pm 1 \cdot 8 \\
92 \cdot 3 \pm 13 \cdot 7 \\
99 \cdot 6 \pm 8 \cdot 4\end{array}$ & $\begin{array}{c}43 \cdot 6 \pm 1 \cdot 2 \\
56 \cdot 8 \pm 2 \cdot 9 \\
123 \cdot 2 \pm 6 \cdot 8 * \\
47 \cdot 9 \pm 4 \cdot 1^{*}\end{array}$ & $\begin{array}{r}42 \cdot 4 \pm 1 \cdot 8 \\
58 \cdot 4 \pm 1 \cdot 1 \\
130 \cdot 9 \pm 9 \cdot 9 \\
56 \cdot 7 \pm 2 \cdot 9\end{array}$ \\
\hline
\end{tabular}

The medium for all cells contained 126 m-equiv. $/ 1 \mathrm{Na}, 50 \mathrm{~m}$-equiv. $/ 1 \mathrm{~K}$. Figures are means $\pm S$.E. for the number of determinations in parentheses.

* Significantly different from control, $P<0.05$.

+ Fresh spermatozoa were twice washed in artificial medium before analysis.

Table 1 summarizes the data for these experiments. Slow-cooling of fresh spermatozoa had no significant effect on the degree of eosin permeability of the cells, nor on their extracellular space. Fresh cells showed considerable variation in cell water content between samples, some of this variance being perhaps attributable to the extracellular space error. The mean water content of fresh spermatozoa is, however, in good agreement with estimates made by other methods (Barer, 1956; Benedict, Schumaker \& Davies, 1967).

Fresh cells had a significantly higher potassium and lower sodium concentration than the medium, indicating that true concentration gradients exist between cells and environment. In cooled spermatozoa, there was a significant increase in cell sodium and decrease in cell potassium. The mean values for sodium and potassium in cooled cells were found to be close to those of the medium, and to show less variance than control values for both ions. Wide variations in sodium and potassium content of fresh bull spermatozoa have previously been reported (Gragle, Salisbury \& VanDemark, 1958; Yassen \& Foote, 1967).

Subsequent re-incubation of cooled spermatozoa for $2 \mathrm{hr}$ at $25^{\circ} \mathrm{C}$ did not 
result in any significant change in cell sodium or potassium concentration. Alteration of re-incubation temperature to 15 or $30^{\circ} \mathrm{G}$, prolonging the reincubation period to $3 \mathrm{hr}$ or omission of calcium from the re-incubation were all without effect.

The dissipation of gradients between spermatozoa and medium on cooling fresh bull spermatozoa suggests that these gradients may be maintained by cellular metabolism. Although slow cooling of the cells avoided cold-shock as indicated by eosin permeability, such cooled cells showed no evidence of being able to restore cation gradients on re-incubation under various conditions calculated to promote cell metabolism. It is possible that cooled cells are potentially capable of actively transporting sodium and potassium ions but that appropriate conditions of re-incubation were not achieved in these experiments. Alternatively the cells may have suffered membrane damage on cooling which was not reflected in an increased eosin permeability. Full understanding of the distribution of alkali cations between spermatozoa and environment requires knowledge of the state of sperm intracellular solutes and their exchangeability with the solutes in the medium. While it has been shown that sodium and potassium of marine invertebrate spermatozoa can freely exchange with the medium, and that separated head-midpieces retain ionic gradients while tails do not (Steinbach \& Dunham, 1961), corresponding information on mammalian spermatozoa is not yet available.

\section{REFERENCES}

Barer, R. (1956) Phase contrast and interference microscopy in cytology. In : Physical Techniques in Biological Research, Vol. 3, p. 63. Eds. G. Oster and A. W. Pollister, Academic Press, New York.

Benedict, R. C, Schumaker, V. N. \& Davies, R. E. (1967) The buoyant density of bovine and rabbit spermatozoa. J. Reprod. Fert. 13,237.

Campbell, R. C, Hancock, J. L. \& Rothschild, Lord (1953) Counting live and dead bull sperman tozoa. J. exp. Biol. 30, 44.

Cragle, R. G., Salisbury, G. W. \& VanDemark, N. L. (1958) Sodium, potassium, calcium and chloride distribution in bovine semen. J. Dairy Sci. 41, 1267.

Quinn, P. J. \& White, I. G. (1967) Active cation transport in dog spermatozoa. Biochem. J. 104, 328.

Quinn, P. J. \& White, I. G. (1968) The transport of cations by ram and bull spermatozoa. Aust. J. biol. Sci. $21,781$.

Quinn, P.J., Whito, I. G. \& Wlirrick, .. R. (1965) Studies of the distribution of the major cations in semen and male accessory secretions. F. Reprod. Fert. 10, 379.

Steinbach, H. B. \& Dunham, P. B. (1961) Ionic gradients in some invertebrate spermatozoa. Biol. Bull. mar. biol. Lab., Woods Hole, 120, 411.

Yassen, A. M. \& Foore, R. H. (1967) Sodium and potassium content of bull spermatozoa during processing prior to freezing. F. Anim. Sci. 26, 1104. 